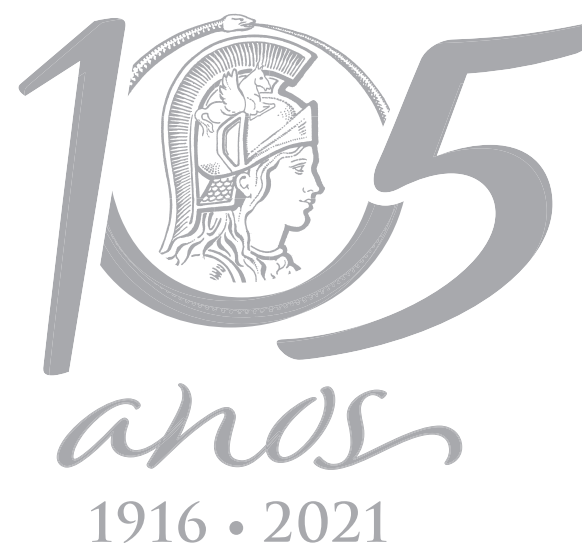

\title{
ECOSYSTEMS
}

\section{Classification of homogeneous regions of vegetation cover in the State of Rio Grande do Sul, Brazil and its temporal dynamics, using AVHRR GIMMS and MODIS data sets}

\author{
ANA PAULA A. CORDEIRO, RITA DE CÁSSIA M. ALVES, ANA PAULA L.W. STEFFLER, \\ VAGNER P. MENGUE, DENISE C. FONTANA, VINICIUS S. ROGLIO \& LAURINDO A. \\ GUASSELLI
}

\begin{abstract}
This study aimed to classify the homogeneous regions of vegetation cover, which occur in Rio Grande do Sul, formed by clustering of pixels with same pattern of temporal variability of the Normalized Difference Vegetation Index (NDVI) of AVHRR GIMMS and MODIS series and to compare their temporal dynamics. We use $\mathrm{K}$ means cluster analysis for defining homogeneous regions, based on the temporal variability of GIMMS (8 km spatial resolution) and MODIS (1 km spatial resolution) NDVI data sets, using monthly images mean from 2000 to 2008 (overlapping period); and we analyzed the annual pattern of NDVI. Accuracy assessment was done with Landsat images. The results show that the temporal variability of GIMMS and MODIS NDVI allows to delimit similar homogeneous regions in order to mapping the main vegetation cover. MODIS series shows a greater detail in the definition of the regions, but with compatibility with those generated by GIMMS. The temporal dynamics show a typical seasonal pattern, with variations of NDVI amplitude between the groups, that allow to monitor phenological changes. The deviations from calibration between times series are linear, which would facilitate a correction in order to construct a long synthetic time series for studies of land cover change.
\end{abstract}

Key words: agriculture, classification, clustering, forest, grassland, kmeans.

\section{INTRODUCTION}

Homogeneous regions obtained by classification techniques, such as cluster analysis, are useful for monitoring of vegetation cover (Gurgel et al. 2003). In environmental context, the definition of these regions can be useful in the elaboration of plans for management of natural resources and for delimitation of priority areas for conservation. In agricultural context, biomass monitoring is useful for crop forecasting and may also support the monitoring of the expansion or retraction of agricultural frontiers (Fontana et al. 1998).
Normalized Difference Vegetation Index (NDVI) images of GIMMS (Global Inventory Modeling and Mapping Studies) time series, derived from AVHRR (Advanced Very High Resolution Radiometer) on board NOAA (National Oceanic and Atmospheric Administration) satellites, are a consistent source of information of vegetation dynamics on space-time. In the long term, these data allow to document continuous changes in the biosphere, which is especially important for monitoring of vegetation growth and distribution, and to evaluate changes in land use and land cover (Fensholt et al. 2009, 
Beck et al. 2011). This time series has images available freely, high temporal frequency with daily acquisition and global coverage. But the greatest advantage of this time series is to be the longest historical series, with continuous data since 1981, and for this reason it has been used for studies of large areas such as biomes and broad areas of similar agriculture crops/ systems.

Gurgel et al. (2003) analyzed AVHRR GIMMS NDVI data set, from monthly images (1982 to 1993 period), using cluster analysis for characterizing the spatial-temporal variability of the main vegetation cover in Brazil, with a spatial resolution of $64 \mathrm{~km}$. In Rio Grande do Sul, it was classified into two vegetation types: Campanhas gaúchas (southern Brazilian Steppe region) and Floresta ombrófila (Ombrophilous Forest). The authors recommend that the technique could be applied in NDVI data with a spatial resolution of $8 \mathrm{~km}$, which would allow a better separation of the various vegetation types. None accuracy assessment was not done. The results were compared and related to one or more vegetation types of the map obtained from official Institute of statistical or geoscientific information of Brazil (IBGE).

Cordeiro et al. (2017) used a long series (1982 to 2008 period) for classifying the vegetation cover in Rio Grande do Sul by temporal variability of AVHRR GIMMS NDVI (with a spatial resolution of $8 \mathrm{~km}$ ), using cluster analysis. Six homogeneous regions were defined, allowing to identify and map the main vegetation types, with same pattern of variability of NDVI. These regions used as mask for extracting and making of the temporal profile of NDVI allow biomass or phenology modeling, where the knowledge of vegetation dynamics is essential.

With higher spatial resolution than AVHRR GIMMS series, since 2000's, MODIS (Moderate Resolution Imaging Spectroradiometer) images of Terra platform, in the form of vegetation indices, have also been tested and used for monitoring of vegetation dynamics (Rosemback et al. 2010, Costa \& Guasselli 2017, Wagner et al. 2018). This because the understanding of the average conditions and annual dynamics in biomes is essential to support studies that assess trends of changes in vegetation due to anthropogenic and/or climatic causes.

Considering that it is possible to group homogeneous regions of vegetation by clustering, based on the temporal variability of NDVI and to monitor annual seasonality of these groups, as shown by Cordeiro et al. (2017), using AVHRR GIMMS time series, with a spatial resolution of $8 \mathrm{~km}$, the hypothesis of this work is that it is possible to obtain a greater detail in the definition of these regions when using MODIS time series, but with compatibility with those regions and profiles generated by GIMMS data set. This knowledge would enable, in future works, the construction of a long synthetic time series, with extension in the available period of data of MODIS, to studies of land cover change. Therefore, the objective of this work was to classify homogeneous regions of vegetation cover in Rio Grande do Sul - Brazil, formed by clustering of pixels with same pattern of temporal variability of NDVI of AVHRR GIMMS and MODIS series and to compare their temporal dynamics of NDVI.

\section{MATERIALS AND METHODS}

\section{Study Area}

The analysis covered the State of Rio Grande do Sul, in the extreme south of Brazil (between $27^{\circ} 03^{\prime} 42^{\prime \prime}$ and $33^{\circ} 45^{\prime} 09^{\prime \prime} \mathrm{S}, 49^{\circ} 42^{\prime} 41^{\prime \prime}$ and $57^{\circ} 40^{\prime} 57^{\prime \prime}$ W), with a total area of $281,748 \mathrm{~km}^{2}$, including the lagoons of Patos $\left(10,049 \mathrm{~km}^{2}\right)$ and Mirim (2,811 km²). Vegetation of Rio Grande do Sul comprises two large Biomes: Pampa (grasslands) 
and Atlantic Forest (IBGE 2004), and it is divided in eight phytoecological regions: Dense Ombrophilous Forest; Mixed Ombrophilous Forest (also known as Araucaria Forest); Semideciduous Seasonal Forest; Deciduous Seasonal Forest; Steppe region (Campos de Cima da Serra and Campanha); Savannah-steppe (Campos com espinilho); Primary formations areas; and, Ecological tension zones.

\section{NDVI Data sets}

Monthly images of Maximum Value Composition from GIMMS NDVI, with a spatial resolution of $8 \mathrm{~km}$, from AVHRR/NOAA, were used. This time series comprises a long-term collection of global images (since 1981), obtained, free of charge, at NASA's (National Aeronautics and Space Administration) <http://ftp.glcf.umd.edu/ data/gimms/>.

Also, NDVI time series from MODIS, on board Terra, available by NASA Earth Observation Program, free of charge, were used (Product MOD13A3 - Vegetation Indices Monthly L3 Global, spatial resolution of $1 \mathrm{~km}$, Grid SIN, V006 version). The images were downloaded at <https://lpdaac. usgs.gov/dataset_discovery/modis/modis_ products_table/mod13a3_v006> and mosaic was processed. Despite the availability of MODIS NDVI images with $250 \mathrm{~m}$ spatial resolution, we chose to use MODIS images with $1 \mathrm{~km}$ resolution, due to their available at a monthly time step, allowing the comparison with GIMMS series.

The period from 2000 to 2008 was chosen because it was the period of temporal overlap of the two NDVI time series (GIMMS and MODIS). For both time series, the study area was projected for Lat Long Geographic Coordinate System and cut by the boundary of the Rio Grande do Sul, besides water bodies, urban centers were masked out using IBGE cartographic base. Representing the temporal variability of NDVI, twelve monthly images (from January to December) mean from 2000 to 2008 were calculated.

\section{GIMMS and MODIS image classification}

For each data set (GIMMS and MODIS), the twelve monthly images were used as input for clustering of the pixels in homogeneous regions of NDVI in Rio Grande do Sul, using Kmeans technique.

Kmeans unsupervised classification is a clustering algorithm that uses the Euclidean distance to calculate the distances between each pixel and the center of the nearest group (centroid), in order to minimize the square of the error. The initialization of centroids $\mathrm{K}$ assigns each pixel to the group whose centroid is closest, updates the centroids of the group and repeats the process, reassigning the objects (NDVI values) to the groups based on similarity, until a convergence criterion is satisfied. The criterion may be that there are no more reassignments of objects from one group to another (until $\mathrm{K}$ centroids are fixed), or when the quadratic error stop to decrease significantly, after some iterations. Due to results obtained in previous tests it was chosen to use the initialization of centroids by diagonal axis (Cordeiro et al. 2017). Clustering process stops when one of the conditions is satisfied: the percentage of pixels migration is less than $1 \%$ of the pixels of the whole image, or the maximum number of 50 iterations is reached.

The set of pixels that formed each homogeneous region of NDVI was used to extract monthly values of NDVI and to make average profiles (from 2000-2008), in order to characterize the annual variability of NDVI for each vegetation type for the two data sets.

\section{Accuracy assessment}

Evaluation of the NDVI homogeneous regions classification was made by confronting the 
reference stratified random sample of points (1,200 polygons) collected on mosaic of Landsat images. The reference map used to validate the mapping was the mosaic of the Rio Grande do Sul from 22 images of the Landsat 5 TM and 7 ETM+ satellite (1999, 1; 2000, 1; 2001, 3; 2002, 11 and 2003, 6 images) (Hasenack \& Cordeiro 2006). The data were tabulated in a confusion matrix, which it was possible to apply the calculation of the overall accuracy, accuracy of the producer and accuracy of the user.

The similarity of MODIS and GIMMS data sets was evaluated by the existence or not of differences in average annual values of NDVI of each vegetation type. For this, statistics of comparison of measurement (mean, standard deviation and standard error of difference) were analyzed by paired T test; Pearson correlation ( $r$ ) and their respective $p$-values.

\section{RESULTS AND DISCUSSION}

\section{Homogeneous regions of NDVI}

The cluster analysis using the monthly images of GIMMS NDVI mean from 2000 to 2008 (Figure 1), showed great similarity with the results obtained by Cordeiro et al. (2017), which analyzed a period from 1982 to 2008. This result may indicate that, in the unavailability of a long time series, a shorter period may be used for clustering of the vegetation cover in Rio Grande do Sul. But this still needs to be better evaluated and the minimum size of the time series determined.

The cluster analysis using the monthly images of MODIS NDVI (mean from 2000 to 2008) generated homogeneous regions of NDVI quite similar to the GIMMS (Figures 1 and 2). Using MODIS NDVI images, a set of pixels with background information formed a coastal sand line, along the entire coast of the Rio Grande do Sul, that it was identified as Dunes.

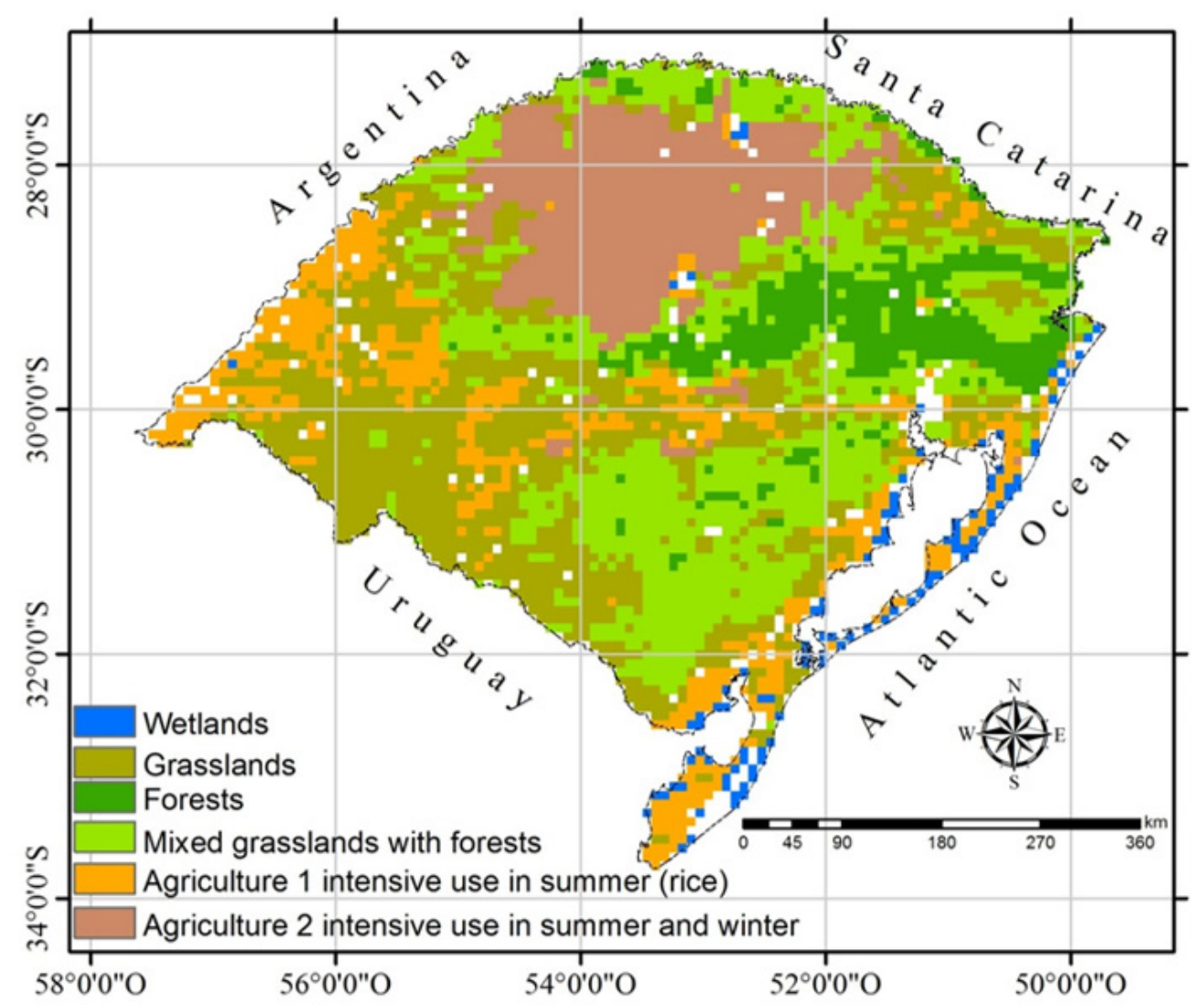

Figure 1. Homogeneous regions of vegetation cover from temporal variability of GIMMS NDVI in Rio Grande do Sul - Brazil, using monthly images mean from 2000 to 2008. 
For both data sets (Figures 1 and 2), the group classified as Wetlands was located along the coast of the Atlantic Ocean and near water bodies such as the rivers: Uruguai, Ibicuí, Jacuí, Passo Fundo, Guaiba; and the lagoons: Patos, Mirim, Mangueira.

The group identified as Agriculture 1 intensive use in summer (rice) occupied areas that are predominantly occupied by rice cultivation in spring-summer and fallow with grasslands in autumn-winter (Figures 1 and 2). The rice cultivation area covered by GIMMS NDVI was 3,980,800 ha, while by MODIS NDVI, it was of 3,358,100 ha. The maximum area cultivated with irrigated rice in the State during the study period was 1,065,633 ha in 2008 (IBGE 2018). This overestimation may have occurred by the inclusion of areas that alternate rice and fallow with grasslands or crop rotation with rainfed crops, in general, these areas are rotated every three-four years. Besides, according to Mengue \& Fontana (2015), areas with crops, such as soybean and corn, with similar spring-summer cycle, can be included in rice mapping due to spectral confusion associated to thickness of the organic matter content suspended in the water. However, this area, mainly that obtained from MODIS, was similar to cultivation potential area of rice in the State of 3,322,037 ha, calculated by Klering et al. (2013) with other classification methodology. The technique, although not be indicated for estimating/quantifying areas with rice, portrayed potential areas for the cultivation, which they were more evident when using MODIS images.

The group Agriculture 2 intensive use in summer and winter refers to areas with crops for grain production, especially soybean (Gusso et al. 2012, Santos et al. 2014). In addition to corn and beans and, on a smaller scale, sorghum,

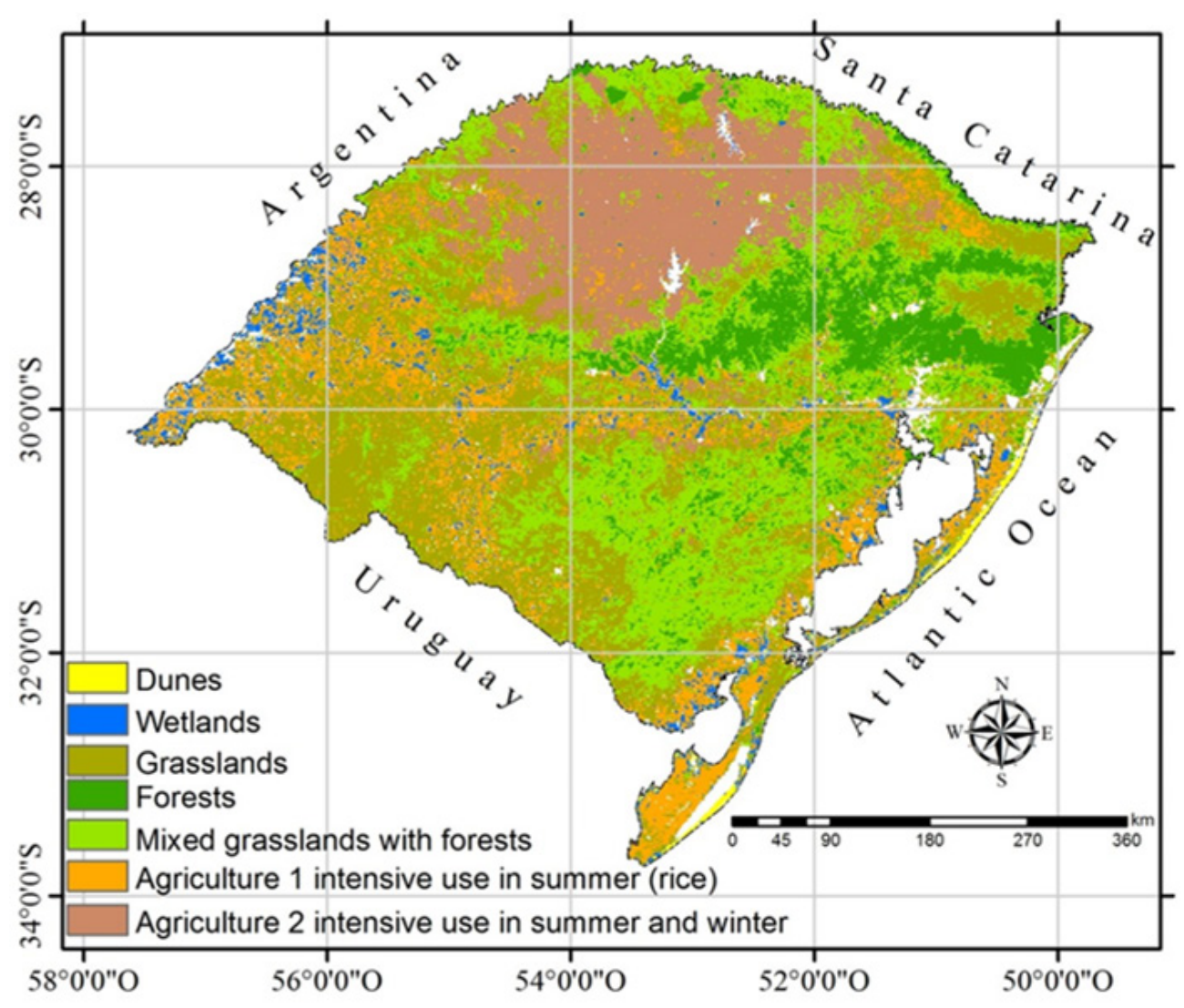

Figure 2.

Homogeneous regions of vegetation cover from temporal variability of MODIS NDVI in Rio Grande do Sul - Brazil, using monthly images mean from 2000 to 2008. 
peanut and sunflower (CONAB 2018) in springsummer. In autumn-winter, cereals, mainly wheat, but also oats, barley, canola, triticale and rye (CONAB 2018), are cultivated in this area. The highest grain production of the State is concentrated in this region (Figures 1 and 2). Although the soybean cultivation has advanced towards the south of the State (Mengue \& Fontana 2015, Kuplich et al. 2018), these areas, practically, were not detected in the present study, probably by the low expressiveness between 2000 to 2008. In the case of wheat, oats and barley, the area of cultivation covers part of the southern of the State (CONAB 2018), extrapolating the largest grain-producing area, but with less expressiveness. It should be noted that the objective of the clustering was not to estimate/quantify areas of soybean crops, as in Gusso et al. (2012), Santos et al. (2014), Mengue \& Fontana (2015) and Kuplich et al. (2018), but to identify and map the main vegetation cover, with pattern of variability of NDVI similar.

The group classified as Grasslands occupied an extensive area of the Rio Grande do Sul (Figures 1 and 2). It is a consistent result, since the grasslands are the dominant landscape, covering $75 \%$ of the State. According to Boldrini et al. (2010), 62\% of these are located in Pampa Biome. Probably, in this group were natural and cultivated grasses, due to similar variability of NDVI.

The group Mixed grassland with forests was thus identified, precisely because it includes remaining forests of the Atlantic Forest Biome. It was present, mostly, in the Southeastern Serra and in areas close to Atlantic Forest Biome, as well as at Uruguay River valley and around the major grain producing region (Figures 1 and 2). According to Boldrini et al. (2010), areas currently covered by grassland, were originally occupied by sub-shrubs and small trees, which were gradually cut or burned. Hasenack et al. (2010) classified a similar area as Shrubby grassland and Seasonal Forest, both with dominant physiognomy composed by mosaic of forest and grassland.

The group classified as Forests (Figures 1 and 2) occupied areas of remaining forests of Atlantic Forest Biome, similar to the map of Guasselli et al. (2006). These areas included Mixed Ombrophilous Forest; Semideciduous Seasonal Forest, Dense Ombrophilous Forest and Deciduous Seasonal Forest. Hasenack et al. (2010) classified as Forests, areas similar to those in our map from temporal variability of NDVI (Figures 1 and 2), however, in their study mapping was based on several information plans such as altitude, slope, soil, vegetation and land use.

In Figures 1 and 2 was well evidenced the highest level of spatial detail in the definition of each homogeneous region, obtained by MODIS NDVI, which it was expected due to the much higher spatial resolution of MODIS images in comparison with GIMMS NDVI. There is no outstanding advantage of either data set, the best is the one that suits the demands of the study developed. In general, images with higher spatial resolution are required in the local studies, whereas in large or even global studies, less detailed images are better for understanding the great patterns of vegetation.

\section{Accuracy assessment}

The confusion matrix resulting from the comparison between the MODIS classification and reference map, for each homogeneous region of vegetation cover in Rio Grande do Sul is showed at Table I. Despite the spatial resolution of MODIS $(1 \mathrm{~km})$ and the heterogeneity of the study area, the overall accuracy, obtained by dividing the sum of the main diagonal (highlighted in gray 3,144 ) by the total number of points sampled (number in bold 4,174) was of 
Table I. Confusion matrix resulting from the comparison between the MODIS classification and reference map, for each homogeneous region of vegetation cover in Rio Grande do Sul - Brazil.

\begin{tabular}{|c|c|c|c|c|c|c|c|c|c|}
\hline \multirow[b]{2}{*}{ MODIS } & \multirow[b]{2}{*}{ Wetland } & \multicolumn{2}{|c|}{ Agric. 1} & \multirow{2}{*}{$\begin{array}{c}\text { Agric. } 2 \\
\text { int. } \\
\text { use in } \\
\text { summer } \\
\text { / winter }\end{array}$} & \multirow{2}{*}{$\begin{array}{c}\text { Mixed } \\
\text { grassland } \\
\text { with } \\
\text { forest }\end{array}$} & \multirow[b]{2}{*}{ Forest } & \multirow[b]{2}{*}{ Dunes } & \multirow[b]{2}{*}{ Total } & \multirow[b]{2}{*}{$\begin{array}{l}\text { User } \\
\text { Accuracy } \\
\text { (\%) }\end{array}$} \\
\hline & & $\begin{array}{l}\text { int. } \\
\text { use in } \\
\text { summer } \\
\text { (rice) }\end{array}$ & Grassland & & & & & & \\
\hline Wetland & 28 & 252 & 0 & 0 & 0 & 3 & 10 & 293 & 9,56 \\
\hline $\begin{array}{l}\text { Agriculture } 1 \\
\text { intensive use } \\
\text { in summer } \\
\text { (rice) }\end{array}$ & 44 & 372 & 28 & 12 & 11 & 52 & 19 & 538 & 69,15 \\
\hline Grassland & 25 & 63 & 549 & 10 & 186 & 35 & 0 & 868 & 63,25 \\
\hline $\begin{array}{l}\text { Agriculture } 2 \\
\text { intensive use } \\
\text { in summer } \\
\text { and winter }\end{array}$ & 0 & 21 & 2 & 359 & 1 & 0 & 0 & 383 & 93,73 \\
\hline $\begin{array}{l}\text { Mixed } \\
\text { grassland } \\
\text { with forest }\end{array}$ & 20 & 2 & 32 & 2 & 311 & 113 & 0 & 480 & 64,79 \\
\hline Forest & 0 & 0 & 1 & 0 & 84 & 1480 & 0 & 1565 & 94,57 \\
\hline Dunes & 0 & 2 & 0 & 0 & 0 & 0 & 45 & 47 & 95,74 \\
\hline Total & 117 & 712 & 612 & 383 & 593 & 1683 & 74 & 4174 & \\
\hline $\begin{array}{c}\text { Producer } \\
\text { Accuracy (\%) }\end{array}$ & 23,93 & 52,25 & 89,71 & 93,73 & 52,45 & 87,94 & 60,81 & & 75,32 \\
\hline
\end{tabular}

$75 \%$. To obtain the accuracy of the classification, the number of correct points in each category was divided by the total sampled in each row or column of the confusion matrix. At the column level, accuracy of the producer indicates the probability that a reference point of the class has been classified correctly, this denotes a measure of omission error (when an element is deleted from the class to which it belongs). However, if the total number of correct points in a category is divided by the total number of points classified in that category, then this result is a measure of commission error (when an element is included in a class to which it does not belong), then accuracy of the user or reliability indicates that a classified point on the image, actually, represents that category (Congalton \& Green 2009).

It is possible to observe in Table I that Agriculture 2 intensive use in summer and winter was the one that achieved the highest probability of correct answers in the classification in both, accuracy of the producer and accuracy of the user (93.73\%). Followed by Forests that presented 
$87.94 \%$ accuracy of the producer and $94.57 \%$ accuracy of the user. Dunes presented $95.74 \%$ accuracy of the user, but only $60.81 \%$ accuracy of the producer. In turn, Grasslands presented $89.71 \%$ accuracy of the producer, but only $63.25 \%$ of user accuracy. Agriculture 1 intensive use in summer (rice) and Mixed grasslands with forests showed $69.15 \%$ and $64.79 \%$ accuracy of the user and, $52.25 \%$ and $52.45 \%$ accuracy of the producer, respectively. All considered from good to excellent (Congalton \& Green 2009). The lowest percentages of accuracy occurred in the Wetlands, with great part of pixels confused with Agriculture 1 intensive use in summer (rice).

In converting the polygons from vector to raster, the total number of pixels generated did not reach the minimum size of a reliable sample to generate the confusion matrix for comparison between the GIMMS classification and reference map. Despite this, the homogeneous regions of NDVI showed an important association with the environmental macrozoning (Guasselli et al. 2006): remaining forests; mixed grasslands with forests in the Southeastern Mountain of the Rio Grande do Sul (mixed grasslands and sub-bushes); grasslands; coastal dunes; the agricultural areas, mainly the grain producing region in the northern half of the State; rice cultivation areas in the southern half of the State and in the western of the State. The Rio Grande do Sul macrozoning was accomplished by integrating orbital data of different characteristics and other cartographic products (Landsat mosaic; temporal NDVI/ NOAA combination; geomorphologic map; and altimetric map).

The main advantage of clustering by the temporal variability of NDVI is the practicality of the method, avoiding the need of numerous information plans, such as soil maps, altimetry, land use and occupation, generally necessary for thematic maps, such as in Guasselli et al. (2006), as well as onerous fieldwork. The proposed clustering by the temporal variability of GIMMS and MODIS NDVI adequately represented the main homogeneous regions of vegetation cover, with same temporal dynamic (Figures 1 and 2).

The images availability, free of charge, and the fast and satisfactory applicability allow to test this methodology in other regions, since it is fundamental to respect the local specificities, mainly associated with characteristics and size of the areas occupied by different types of vegetation.

\section{Temporal profiles of NDVI}

Mean annual profiles of GIMMS and MODIS NDVI distinct vegetation types are shown in Figure 3a, 3b, 3c, 3d, 3e and 3f.

The lowest values of NDVI were observed in the mean annual profile of Dunes (Figure 3a), around 0.2 , being this class generated only with MODIS (background information). Dunes showed lower values due to reflectance in red closer to near infrared reflectance than in vegetated areas, which also occurs in sandy areas. With slightly higher values, it was the group Wetlands GIMMS (Figure 3a), whose values were lower in the winter (close to 0.3) and increased during the development of new leaves, reaching the maximum NDVI peak (around 0.40), in February, when the plants were in a full vegetative development stage. In the following months NDVI values decreased. NDVI values of the Wetlands GIMMS were lower than those of MODIS, probably by high spectral mixing nearby the lagoons, and also because Wetlands GIMMS included a large coastal area with pixels of dunes. For these same reasons Wetlands was the homogeneous region of NDVI with the greatest differences between the profiles of both time series. Wetlands MODIS showed a mean annual profile of NDVI similar to the group Agriculture 1 intensive use in summer (rice). However, with lower values in 

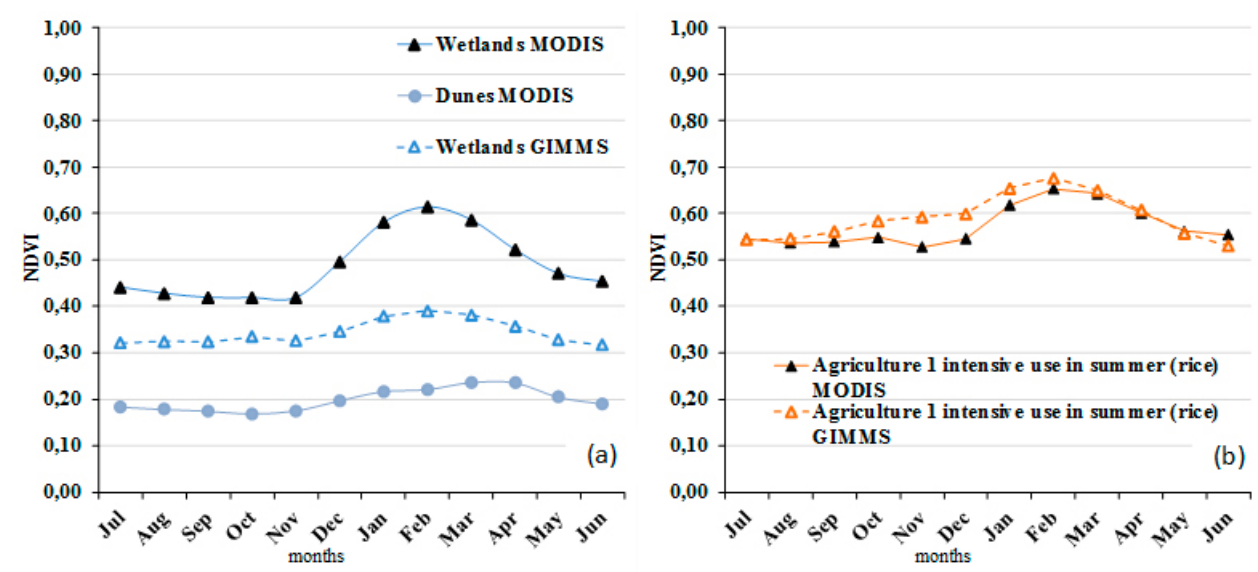

Figure 3. Mean annual profiles from 2000 to 2008 of GIMMS and MODIS NDVI of the vegetation types: (a) Wetlands and Dunes; (b) Agriculture 1 intensive use in summer (rice); (c) Agriculture 2 intensive use in summer and winter; (d) Grasslands; (e) Mixed grasslands with forests; and (f) Forests in Rio Grande do
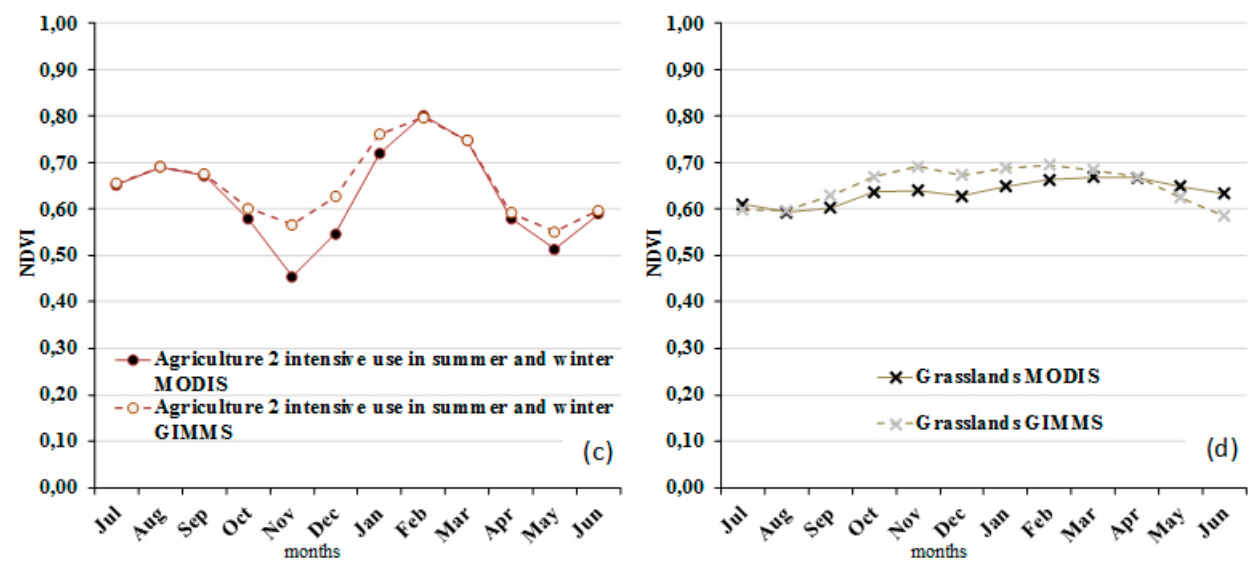
Sul - Brazil.
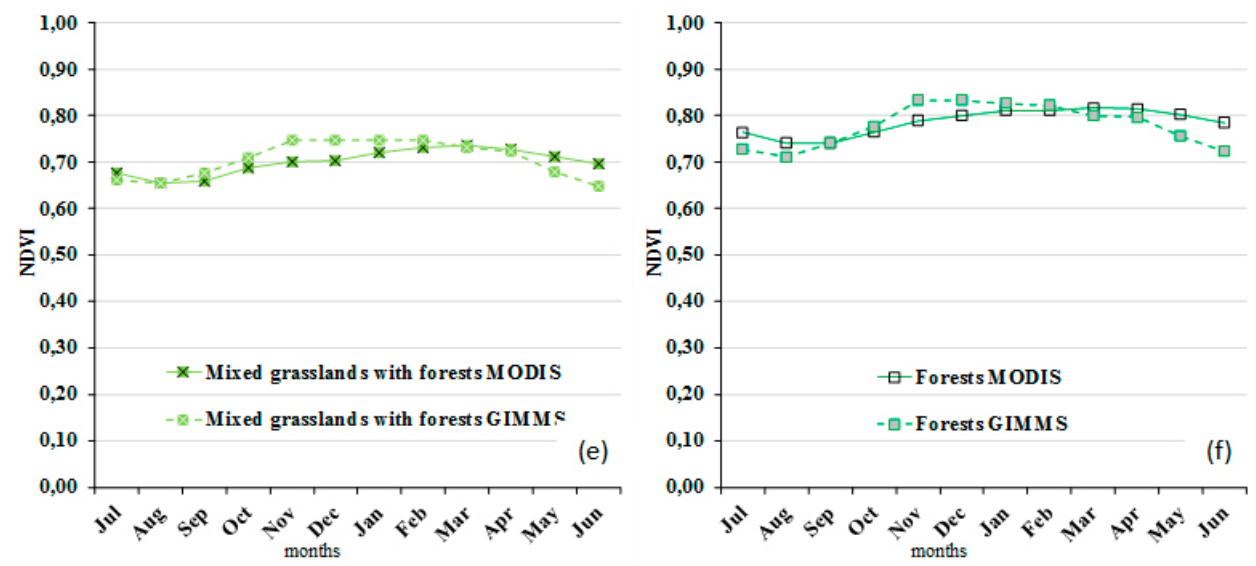

the winter (around 0.45), and increasing during the emergence of new leaves, reaching the peak in February (0.6). Probably, some areas of rice were included as being wetland, especially in the Western Frontier of the State.

A decrease in NDVI in the months of October and November would be expected as consequence of the entry of water into rice fields, in the mean annual profile of Agriculture 1 intensive use in summer (rice), but this was only observed in the case of MODIS NDVI in November (Figure $3 b$ ). On the other hand, the GIMMS NDVI profile for the group Agriculture 1 intensive use in summer (rice), increasing since 
the spring (close to 0.60), in months when the NDVI should be reduced by the entrance of water, indicated a spectral mixing with the presence of grasslands (fallow areas), which at this period were in growing season. The maximum NDVI peak occurred in February (0.68 for GIMMS NDVI and 0.66 for MODIS NDVI), in the stages of flowering and beginning of grain filling of the rice. NDVI decreased in the autumn, due to loss of green biomass and rice harvest.

The profile of the group Agriculture 2 intensive use in summer and winter was different of the others because it presented two peaks of NDVI (Figure 3c). The first peak occurred when autumn-winter crops reached the maximum biomass in August (both 0.69) and September (0.68 in the GIMMS case and 0.67 in the MODIS), which corresponded to the end of the vegetative growth and flowering of wheat, the predominant cereal in most of the area (Junges \& Fontana 2011). NDVI decreased during the harvest of autumn-winter cereal crops, which in most of the area occurs in November and in the sowing period of the spring-summer crops, which in this month have a strong spectral response of the soil or straw, with GIMMS NDVI of 0.57 and MODIS NDVI of 0.45 . This difference was probably due to greater spectral mixing within the GIMMS pixels. The second maximum of NDVI occurred in February (both 0.80), that corresponds to the flowering and/or grain filling period of soybean, dominant crop in this region (Gusso et al. 2012, Santos et al. 2014). During this period, the crop had the highest biomass. The values were higher than autumn-winter cereals because leguminous plants have leaf, architecture and canopy characteristics different of those that are grasses, affecting the reflectance properties (Cordeiro et al. 2017). In March, at the beginning of the harvest, NDVI was 0.75 for both time series, decreasing in the following months. NDVI increased again from May, in the sowing of the autumn-winter cereals (Junges \& Fontana 2011).

Grasslands (Figure 3d) showed a minimum NDVI in the winter (near to 0.6), when most of the vegetation was in senescence due to the low temperatures and lower solar radiation, resulting in low availability of biomass, which was reflected in lower values of NDVI. NDVI increased with the arrival of the spring, in response to the increase of the available energy (temperature and solar radiation). In this period, the cold season plants (most C3 species) were in developmental stage, with MODIS NDVI reaching 0.64 in October and November and GIMMS NDVI to 0.69 in November. In December, both GIMMS and MODIS NDVI of Grasslands decreased. During the summer NDVI increased again due to growth and development of the vegetation, that in this period has strong predominance of $\mathrm{C} 4$ perennial grasses species and some reminiscent of C3 winter species (Wagner et al. 2018, Boldrini et al. 2010). The maximum NDVI, expressing a high production of biomass of these species, was detected by MODIS in March and April (0.67) and by GIMMS in January and February (0.69). After, NDVI decreased in GIMMS and MODIS, due to the reduction of green biomass with the senescence, during the period of lower temperature.

Similar profiles of NDVI and EVI (Enhanced Vegetation Index) were obtained by Wagner et al. (2018), studying 13 ecological regions into the Pampa Biome in Brazil (Rio Grande do Sul) and Uruguay, with MODIS images from 2000 to 2011. The authors found for different grassland types, also, two peaks on the indices, in the autumn (March) and in the spring (October), when cold season species have increased biomass production. They also observed a fast drop in December and the lowest values in the winter, for both indices.

Jacóbsen et al. (2003) using AVHRR/NOAA NDVI images between 1981 and 2000 for different 
macrozones of Rio Grande do Sul verified that, especially in macroregions occupied by grasslands, there was a reduction in NDVI values in December and January, probably due to the growth restriction of the plants as a function of pluvial precipitation does not cover the high atmospheric evaporative demand.

Grasslands mixed with forests (Figure 3e) showed mean annual profile similar to the Grasslands, however, with higher values of NDVI due to the influence of the forest vegetation, with greater vigor than the grasslands. Minimum NDVI occurred in the winter ( 0.65 for GIMMS and 0.66 for MODIS). This due to the senescence of the grasslands and presence of the Semideciduous Seasonal Forest in this group, where 20 to 50\% of the species are deciduous, losing the leaves during this period of intense cold (Rosemback et al. 2010). GIMMS NDVI increased until November and remained high until February (0.75), while the maximum MODIS NDVI was in March (0.74), when the vegetation was at maximum biomass production. Similar profiles of NDVI were obtained by Wagner et al. (2018), with MODIS (2000 to 2011) for two grasslands types in the Pampa Biome: Shrubby grassland and Seasonal Semideciduous Forest, using the ecological regions by Hasenack et al. (2010) as limits, both with dominant physiognomy composed by a mosaic of forest and grassland. The values were closer to 0.74 in March for the Seasonal Semideciduous Forest (Wagner et al. 2018).

Forests (Figure 3f) showed the highest NDVI values of all groups, for both time series. Values of GIMMS NDVI were increasing in the spring (growing season) and reached a plateau from November to January (0.83), when the forest vegetation had a maximum production of green biomass, demonstrating greater vegetative vigor and decreased in the following months. For MODIS, the plateau occurred from January to April (0.81), with a peak in March (0.82). Minimum NDVI occurred in winter, when temperatures were low and forest vegetation was dormant. In the areas occupied by the Deciduous and Semideciduous Seasonal Forest there is a loss of biomass, which reduces the supply of photosynthetic pigments and causes the reflectance in the red band to be slightly higher than in the autumn. However, the radiation in the infrared, which begins to be only partially reflected, has a great reduction in the reflectance (Nora \& Martini 2010). With this, the amplitude of variation between the wavelengths was reduced and determined the lower values of NDVI. Nora \& Martini (2010) and Costa \& Guasselli (2017) studied the seasonal dynamics of the phyto physiognomies (Deciduous Seasonal Forest and Mixed Ombrophilous Forest) in smaller areas of the State, also found a similar phenological pattern: lower NDVI in the months of June and July.

Despite the particularities of each vegetation type, NDVI values were higher when there was low reflectance in the spectral band of red, due to greater absorption of solar radiation by the greater quantity of chlorophyll, and high reflectance in the near infrared band, due to the inability of the vegetative strata to absorb or transmit this type of radiation. When the reflectance peak was shifted to the red, due to the predominance of carotenoids and degradation of chlorophyll and the nearinfrared reflectance decreased due to the degeneration of the mesophilic cell membranes during senescence, a decrease in NDVI values was verified (Fonseca et al. 2007).

\section{Evaluation of the temporal profiles}

The comparison of measurement (mean, standard deviation and standard error of the difference) by the paired T test; Pearson's correlation ( $r$ ) between the mean annual NDVI for MODIS and GIMMS for each homogeneous 
region and respective $p$-values are shown in the Table II.

By paired $T$ test the mean annual values of NDVI of the groups Wetlands, Agriculture 1 intensive use in summer (rice) and Agriculture 2 intensive use in summer and winter were statistically different $(p<0.05)$ between MODIS and GIMMS data sets. In these cases, there is low probability that the mean of the subtractions between the sensors is zero, it is unlikely that the null hypothesis is true. Thus, the null hypothesis was rejected in favor of the alternative hypothesis, that there was difference between the NDVI values for these groups. It should be noted that these three groups showed the highest correlations $(r \approx 1)$ (Table II), suggesting an overestimation of the mean annual NDVI in the Wetlands group and an underestimation in the groups Agriculture 1 intensive use in summer (rice) and Agriculture 2 intensive use in summer and winter in the MODIS data set compared to
GIMMS. However, these calibration deviations from 1: 1 line were linear, which would facilitate a correction, in the construction of a MODIS synthetic time series from GIMMS series.

The temporal profiles of MODIS and GIMMS NDVI data sets satisfactorily described the dynamics of each type of vegetation cover. These results are important in vegetation monitoring systems, especially due to the practicality of the methodology and free availability of the images. In the monitoring of natural vegetation, such as wetlands, grasslands or forests, elaboration of profiles can be useful in case studies, in years with strong occurrence of adverse conditions, such as climatic anomalies. In agricultural monitoring programs it is also possible to evaluate the variability of the profiles between the different crops, serving as a subsidy for biomass modeling.

Table II. Comparison of measurement by paired T test and Pearson's correlation between the mean annual NDVI for MODIS and GIMMS for each homogeneous region of vegetation cover in Rio Grande do Sul - Brazil and respective $p$-values.

\begin{tabular}{|c|c|c|c|c|c|c|}
\hline & MODIS & GIMMS & $\begin{array}{c}\text { Standard } \\
\text { error of } \\
\text { difference }\end{array}$ & p-value & $\begin{array}{l}\text { Pearson's } \\
\text { correlation } \\
\text { (r) }\end{array}$ & p-value \\
\hline Wetlands & $\begin{array}{c}0.487 \pm \\
0.072\end{array}$ & $\begin{array}{l}0.344 \pm \\
0.026\end{array}$ & 0.014 & $<0.001^{\star}$ & 0.957 & $<0.001^{\star *}$ \\
\hline $\begin{array}{l}\text { Agriculture } 1 \text { intensive use in } \\
\text { summer (rice) }\end{array}$ & $\begin{array}{c}0.573 \pm \\
0.044\end{array}$ & $\begin{array}{c}0.592 \pm \\
0.048\end{array}$ & 0.007 & $0.027^{*}$ & 0.847 & $0.001^{\star *}$ \\
\hline Grasslands & $\begin{array}{l}0.636 \pm \\
0.025\end{array}$ & $\begin{array}{c}0.650 \pm \\
0.041\end{array}$ & 0.009 & 0.144 & 0.676 & 0.016 \\
\hline $\begin{array}{l}\text { Agriculture } 2 \text { intensive use in } \\
\text { summer and winter }\end{array}$ & $\begin{array}{c}0.628 \pm \\
0.102\end{array}$ & $\begin{array}{c}0.655 \pm \\
0.081\end{array}$ & 0.011 & $0.028^{*}$ & 0.948 & $<0.001^{* *}$ \\
\hline Mixed grasslands with forests & $\begin{array}{c}0.700 \pm \\
0.027\end{array}$ & $\begin{array}{c}0.706 \pm \\
0.039\end{array}$ & 0.008 & 0.501 & 0.687 & 0.014 \\
\hline Forests & $\begin{array}{c}0.787 \pm \\
0.028\end{array}$ & $\begin{array}{c}0.779 \pm \\
0.046\end{array}$ & 0.009 & 0.416 & 0.721 & 0.008 \\
\hline Total & $\begin{array}{c}0.635 \pm \\
0.110\end{array}$ & $\begin{array}{c}0.621 \pm \\
0.145\end{array}$ & 0.008 & 0.076 & 0.897 & $<0.001$ \\
\hline
\end{tabular}

Representation by mean \pm standard deviation. Paired T-test.

${ }^{*}$ with a statistically significant difference $(p<0.05)$.

$* *$ with a statistically significant correlation $(p<0.05)$. 


\section{CONCLUSIONS}

The temporal variability of GIMMS and MODIS NDVI time series allows to classify similar homogeneous regions, making possible to identify and map the main vegetation cover that occur in Rio Grande do Sul - Brazil. MODIS images allows a greater spatial detail in the definition of the regions, but with compatibility with the regions generated with GIMMS images.

The temporal profiles of MODIS and GIMMS NDVI are characterized by a typical seasonal pattern with variations of NDVI amplitude between the vegetation types, which allows to monitor vegetation phenological variations by their temporal dynamics.

The methodology of clustering by the temporal variability of NDVI is practical, fast, and accessible to group the homogeneous regions with same temporal dynamic of NDVI for both time series. This methodology is indicated for studies of large areas, in which the objectives are to understand the great patterns and the dynamics of the vegetation.

The calibration deviations between time series are linear, which may facilitate a correction, being possible the construction of a long synthetic time series in future works, from the extension in the available period of data of the series of higher resolution (MODIS), for the purpose of studying changes in the land cover.

\section{Acknowledgments}

Especially Molly E. Brown of the Global Inventory Modeling and Mapping Studies (GIMMS) Group. To NASA for producing and sharing of the images. To Coordenação de Aperfeiçoamento de Pessoal de Nivel Superior (CAPES) by Postdoctoral funding. The authors thank the unknown reviewers who carefully reviewed the paper and whose suggestions were useful in improving the manuscript.

\section{REFERENCES}

BECK HE, MCVICAR TR, VAN DIJK AIJM, SCHELLEKENS J, DE JEU RAM \& BRUIJNZEEL LA. 2011. Global evaluation of four AVHRRNDVI data sets: Intercomparison and assessment against Landsat imagery. Remote Sens Environ 115: 2547-2563.

BOLDRINI II, FERREIRA PMA, ANDRADE BO, SCHNEIDER AA, SETUBAL RB, TREVISAN R \& FREITAS EM. 2010. Bioma Pampa: diversidade florística e fisionômica. Porto Alegre: Ed. Pallotti, $64 \mathrm{p}$.

CONAB - COMPANHIA NACIONAL DE ABASTECIMENTO. 2018. Acompanhamento da safra brasileira de grãos safra 2017/18, 5, 5, Brasília, Brasil. p. 1-140. Retrieved from: <http://www.conab.gov.br/OlalaCMS/uploads/ arquivos/18_02_08_17_09_36_fevereiro_2018.pdf>. Access in: March 6th 2018.

CONGALTON RG \& GREEN K. 2009. Assessing the accuracy of remotely sensed data: principles and practices. New York: Lewis Publishers, $2^{\text {nd }}$ ed., 179 p.

CORDEIRO APA, BERLATO MA, FONTANA DC, MELO RW, SHIMABUKURO YE \& FIOR CS. 2017. Regiões homogêneas de vegetação utilizando a variabilidade do NDVI. Ciênc Florest 27(3): 883-896.

COSTA LCB \& GUASSELLI LA. 2017. Comportamento sazonal de remanescentes de fitofisionomias da Mata Atlântica, bacia do rio dos Sinos - RS, por meio de NDVI. Bol Gaúcho de Geografia 44(1-2): 101-118.

FENSHOLT R, RASMUSSEN K, NIELSEN TT \& MBOW C. 2009. Evaluation of earth observation based long term vegetation trends - Intercomparing NDVI time series trend analysis consistency of Sahel from AVHRR GIMMS, Terra MODIS and SPOT VGT data. Remote Sens Environ 113: 1886-1898.

FONSECA EL, FORMAGGIO AR \& PONZONI FJ. 2007. Estimativa da disponibilidade de forragem do bioma Campos Sulinos a partir de dados radiométricos orbitais: parametrização do submodelo espectral. Ciênc Rural 37(6): 1668-1674.

FONTANA DC, BERLATO MA \& BERGAMASCHI H. 1998. Relação entre o índice de vegetação global e condições hídricas no Rio Grande do Sul. Pesqui Agropecu Bras 33(8): 1399-1405.

GUASSELLI LA, SALDANHA DL, SUERTEGARAY DMA, DUCATI JR \& FONTANA DC. 2006. Macrozoneamento do Estado do Rio Grande do Sul. Pesqui Geociênc 33(1): 03-11.

GURGEL HC, FERREIRA NJ \& LUIZ AJB. 2003. Estudo da variabilidade do NDVI sobre o Brasil, utilizando-se a análise de agrupamentos. Rev Bras Eng Agr Amb 7: 85-90. 
GUSSO A, FORMAGGIO AR, RIZZI R, ADAMI M \& RUDORFF BFT. 2012. Soybean crop area estimation by Modis/Evi data. Pesqui Agropecu Bras 47(3): 425-435.

HASENACK H \& CORDEIRO JLP (Org). 2006. Mapeamento da cobertura vegetal do Bioma Pampa. Porto Alegre, UFRGS Centro de Ecologia. 30 p. (Relatório técnico Ministério do Meio Ambiente: Secretaria de Biodiversidade e Florestas no âmbito do mapeamento da cobertura vegetal dos biomas brasileiros). Retrieved from: <https://www. ufrgs.br/labgeo/index.php/dados-espaciais/246mapeamento-da-cobertura-vegetal-do-bioma-pampa.>. Access in: July 10th 2018.

HASENACK H, WEBER E, BOLDRINI I \& TREVISAN R. 2010. Mapa de sistemas ecológicos da ecorregião das Savanas Uruguaias em escala 1:500.000. Porto Alegre: UFRGS - Centro de Ecologia, 22 p. (Relatório Técnico). ISBN 978-85-63843-16-6.

IBGE - INSTITUTO BRASILEIRO DE GEOGRAFIA E ESTATÍsTICA. 2004. Mapa da vegetação do Brasil e Mapa de biomas do Brasil. Retrieved from: <ftp://geoftp.ibge.gov.br/mapas_ tematicos/mapas_murais/>. Access in: January $24^{\text {th }} 2012$.

IBGE - INSTITUTO BRASILEIRO DE GEOGRAFIA E ESTATÍSTICA. 2018. SIDRA - Sistema IBGE de Recuperação Automática. Retrieved from: <http://www.sidra.ibge.gov.br/bda/ pesquisas/pam/>. Access in: March $23^{\text {rd }} 2018$.

JACÓBSEN LO, FONTANA DC \& SHIMABUKURO YE. 2003. Alterações na vegetação em macrozonas do Rio Grande do Sul associados a eventos El Niño e La Niña, usando imagens NOAA. Rev Bras Agromet 11(2): 361-374.

JUNGES AH \& FONTANA DC. 2011. Modelo agrometeorológicoespectral de estimativa de rendimento de grãos de trigo no Rio Grande do Sul. Ceres 58(1): 9-16.

KLERING EV, FONTANA DC, ALVES R, ROCHA J \& BERLATO MA. 2013. Estimativa de área cultivada com arroz irrigado para o estado do Rio Grande do Sul a partir de imagens MODIS. Ciênc e Natura 35(2): 126-135.

KUPLICH TM, CAPOANE V \& COSTA LFF. 2018. O avanço da soja no bioma Pampa. Bol Geográfico do Rio Grande do Sul 31: 83-100.

MENGUE VP \& FONTANA DC. 2015. Avaliação da dinâmica espectro-temporal visando o mapeamento dos principais cultivos de verão no Rio Grande do Sul. Bragantia 74(3): 331-340.

NORA ELD \& MARTINI DZ. 2010. Análise da dinâmica sazonal de fitofisionomias do bioma Mata Atlântica com base em indices de vegetação do sensor MODIS/Terra. Ambiênc 6(1): 97-108.

ROSEMBACK R, FERREIRA NJ, SHIMABUKURO YE \& CONFORTE JC. 2010. Análise da dinâmica da cobertura vegetal na região sul do Brasil a partir de dados MODIS/Terra. Rev Bras Cartogr 2(62): 401-416.

SANTOS JS, FONTANA DC, SILVA TSF \& RUDORFF BFT. 2014. Identificação da dinâmica espaço-temporal para estimar área cultivada de soja a partir de imagens MODIS no Rio Grande do Sul. Rev Bras Eng Agr Amb 18(1): 54-63.

WAGNER APL, WALLAU M, FONTANA DC, CARVALHO PCF \& FRAISSE C. 2018. Vegetation indices variability in the Pampa grasslands in Brazil and Uruguay. Agrometeoros 26(1): 83-92.

\section{How to cite:}

CORDEIRO APA, ALVES RCM, STEFFLER APLW, MENGUE VP, FONTANA DC, ROGLIO VS \& GUASSELLI LA. 2021. Classification of homogeneous regions of vegetation cover in the State of Rio Grande do Sul, Brazil and its temporal dynamics, using AVHRR GIMMS and MODIS data sets. An Acad Bras Cienc 93: e20201278. DOI 10.1590/0001-3765202120201278.

Manuscript received on October 8, 2020;

accepted for publication on February 2, 2021

\section{ANA PAULA A. CORDEIRO 1}

https://orcid.org/0000-0002-1281-7427

\section{RITA DE CÁSSIA M. ALVES ${ }^{1}$}

https://orcid.org/0000-0001-7804-8141

ANA PAULA L.W. STEFFLER ${ }^{1}$

https://orcid.org/0000-0002-6804-4830

VAGNER P. MENGUE ${ }^{2}$

https://orcid.org/0000-0002-2955-1039

\section{DENISE C. FONTANA ${ }^{1}$}

https://orcid.org/0000-0002-2635-6086

\section{VINICIUS S. ROGLIO}

https://orcid.org/0000-0002-6962-233X

\section{LAURINDO A. GUASSELLI ${ }^{1}$}

https://orcid.org/0000-0001-8300-846X 
${ }^{1}$ Programa de Pós-Graduação em Sensoriamento Remoto, Universidade Federal do Rio Grande do Sul, Centro Estadual de Pesquisas em Sensoriamento Remoto e Meteorologia, Av. Bento Gonçalves, 9500, Setor 5, Prédio 44202, 91501-970 Porto Alegre, RS, Brazil

${ }^{2}$ Universidade Federal de Mato Grosso, Curso de Geografia, Departamento de Geografia, Bloco do ICHS, Campus UFMT, Acesso para UFMT, 78068-600 Cuiabá, MT, Brazil ${ }^{3}$ Programa de Pós-Graduação em Psiquiatria e Ciências do Comportamento, Universidade Federal do Rio Grande do Sul, Departamento de Psiquiatria e Medicina Legal, Rua Ramiro Barcelos, 2400, 90035-903 Porto Alegre, RS, Brazil

Correspondence to: Ana Paula Assumpção Cordeiro

E-mail:apacufrgs@yahoo.com.br

\section{Author contributions}

Ana Paula A. Cordeiro (main author) responsible for obtaining and processing the database, result analysis, preparing and writing of draft and manuscript, elaboration and adequacy of tables and figures, translation of the manuscript into English, and perform the reviews request by the reviewers. Rita de Cássia M. Alves: supervision and orientation in the development of the work. Ana Paula L. W. Steffler: resources (MODIS images), responsible for helping in the processing the database, helping in the interpretation of the results in the original draft and in the review, performing revisions and suggestions to improve the quality of the manuscript. Vagner P. Mengue: resources (Polygons and samples), helping in the accuracy assessment in the original draft and in the review, performing revisions and suggestions to improve the quality of the manuscript. Denise $C$. Fontana: concept, methodology, orientation in the development of the work, writing in the original draft and in the final version, performing revisions and suggestions to improve the quality of the manuscript. Vinicius S. Roglifo: formal analysis, helping in the interpretation of the statistical results and writing about them. Laurindo A. Guasselli: orientation in the development of the work, writing in the original draft, performing revisions and suggestions to improve the quality of the manuscript.

\section{(cc) BY}

